\title{
Diffuse coronary artery ectasia in a patient with left main coronary artery trifurcation
}

\author{
Jarosław Wasilewski ${ }^{1}$, Piotr Desperak ${ }^{1}$, Kamil Bujak², Jan Głowacki ${ }^{3}$, Mariusz Gąsior ${ }^{1}$ \\ ${ }_{1}^{1}{ }^{\text {rd }}$ Department of Cardiology, SMDZ in Zabrze, Medical University of Silesia, Katowice, Poland \\ ${ }^{2}$ School of Medicine with the Division of Dentistry in Zabrze, Medical University of Silesia, Katowice, \\ Poland \\ ${ }^{3}$ Department of Diagnostic Imaging, Medical University of Silesia, Silesian Center for Heart Diseases, Zabrze, Poland
}

Kardiochirurgia i Torakochirurgia Polska 2016; 13 (3): 273-275

\begin{abstract}
The term coronary ectasia is reserved to describe a diffuse dilatation of coronary artery segments that have a diameter that exceeds the size of normal adjacent coronary segments by 1.5 times. The occurrence of coronary artery ectasia (CAE) ranges from $3 \%$ to $8 \%$ in the group of patients undergoing coronary computed tomography angiography. The CAE is associated with traditional risk factors and often co-exists with coronary atherosclerosis, which suggests that ectasia may represent an advanced form of atherosclerosis. Nevertheless, there is a lack of consensus on the clinical implications and management of patients in whom the occurrence of CAE is observed, especially in patients without concomitant obstructive atherosclerosis. Here, we present a rare case of a 62-year-old patient with multiple CAEs and left main trifurcation.
\end{abstract}

Key words: coronary artery ectasia, computed tomography, atherosclerosis.

\section{Case report}

We report the case of a 62-year-old man with a history of exertional chest pain, but a negative exercise electrocardiography (ECG) stress test, who was referred to our department for coronary computed tomography angiography (CCTA; Sensation 64, Siemens Medical Solutions, Erlangen, Germany) to exclude significant coronary artery disease. The patient had intermediate pre-test probability of coronary artery disease and no family history of ischemic or congenital heart disease. Physical examination results were normal. The results of blood test were normal. Baseline echocardiogram revealed normal left and right ventricular function and size, with a left ventricular ejection fraction value of $60 \%$, without any valvular disease. The coronary calcium score determined using the method of Agatston was 50.9. The CCTA showed four main epicardial coronary artery ectasias (CAEs; left main trifurcation). The coronaries were dilated to an extent of 5-9 $\mathrm{mm}$ (right coronary artery

\section{Streszczenie}

Termin ektazja wieńcowa zarezerwowany jest do opisu wrzecionowatych dylatacji naczyniowych, przy czym średnica poszerzenia powinna być 1,5 raza większa niż średnica nieposzerzonych sąsiednich segmentów tętnic wieńcowych. Ektazje wieńcowe stwierdza się u 3\% do $8 \%$ pacjentów poddawanych angiografii tomografii komputerowej. W związku z tym, że ektazje często występują u pacjentów z licznymi klasycznymi czynnikami ryzyka, uznaje się je za jedną z form zaawansowanego, miażdżycowego uszkodzenia tętnic. Nie ma konsensusu dotyczącego klinicznego znaczenia ektazji oraz sposobów leczenia, zwłaszcza u pacjentów bez istotnych hemodynamicznie zwężeń. W pracy przedstawiono rzadki przypadek 62-letniego pacjenta z licznymi ektazjami i trifurkacją pnia lewej tętnicy wieńcowej.

Słowa kluczowe: ektazje wieńcowe, tomografia komputerowa, miażdżyca.

ectasia diameter ranged from 5 to $9 \mathrm{~mm}$, left anterior descending artery up to $6 \mathrm{~mm}$, circumflex artery up to $7 \mathrm{~mm}$ and intermediate artery up to $5 \mathrm{~mm}$ ) without significant stenosis (Figs. 1 and 2). To our knowledge, it is the first description of a CAE in a patient with left main trifurcation.

\section{Discussion}

Coronary artery ectasias is a well-recognized, but rare, clinical entity diagnosed during CCTA. In the population undergoing CCTA the incidence of CAE ranges from $3 \%$ to $8 \%$, and it mostly occurs in men [1-3]. By definition CAE is an irregular, saccular dilatation of the coronary artery exceeding the largest diameter of an adjacent healthy vessel more than 1.5 fold after the exclusion of post-stenotic or focal aneurysmal dilatations. It may be diffuse, affecting almost the entire length of a coronary artery, or localized. All coronary arteries can be affected by CAE, but in two thirds of patients an isolated artery dilatation is observed, with a predomi- 


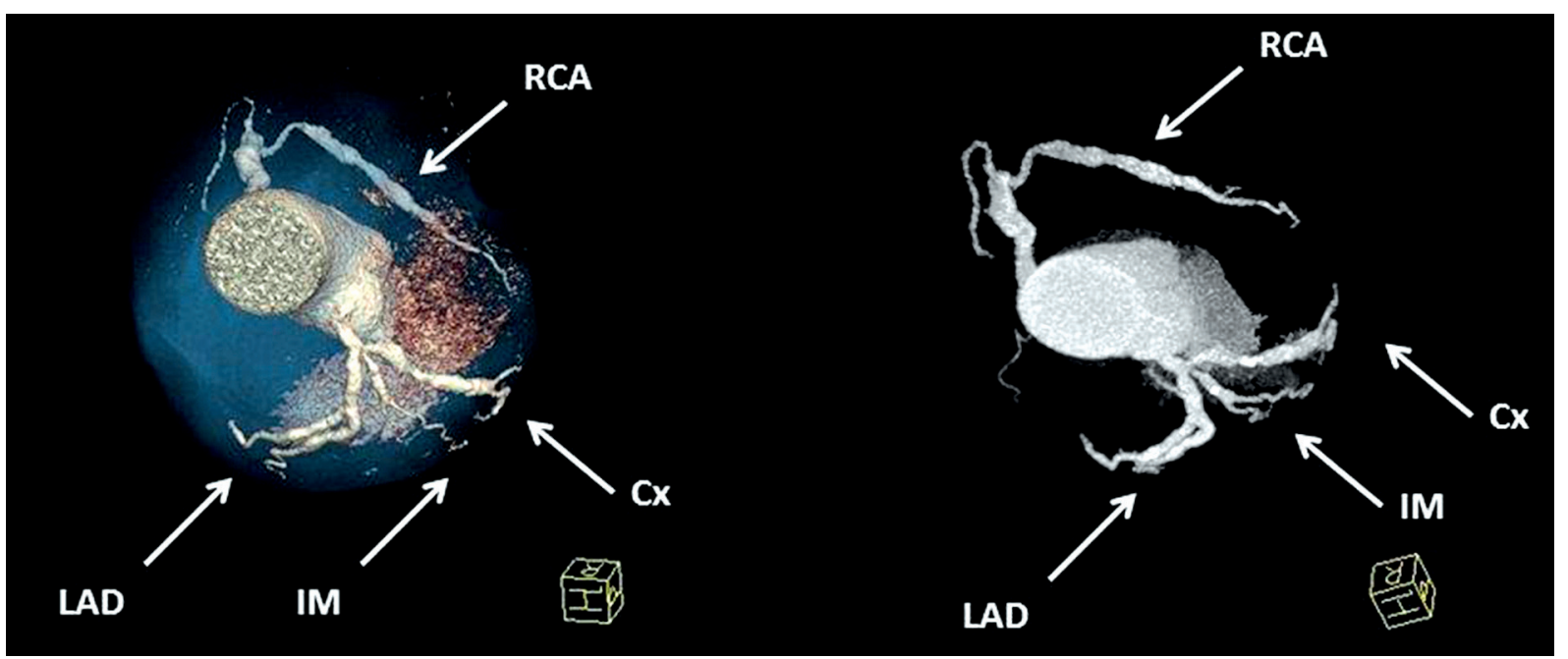

Fig. 1. Volume-rendered images demonstrating irregular, diffuse dilatations of coronary arteries (type I ectasia - including intermediate artery)
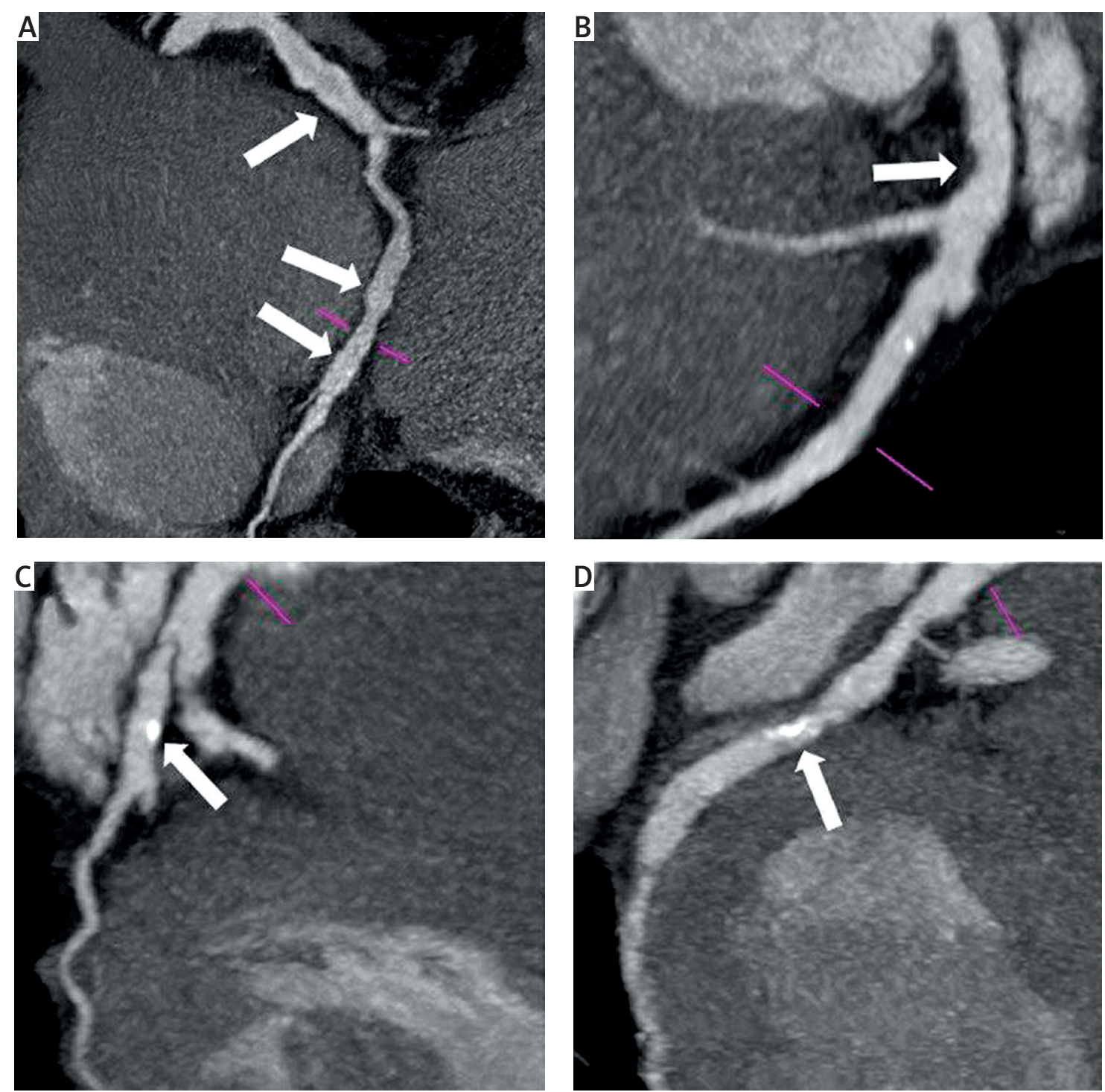

Fig. 2. Curved planar reconstruction. Gated 64-slice CCTA revealing type I ectasia, including the intermediate ramus (C). A - right coronary artery with fusiform ectasias (arrows). B - left anterior descending artery and a non-calcified plaque in the vicinity of the septal perforator (septal artery milking effect) [10] (arrow). C - intermediate artery with fusiform aneurysm and calcified plaque (arrow), D - circumflex branch with fusiform aneurysm and a partially calcified plaque (arrow) 
nant location in the proximal and middle parts of the right coronary artery [4]. The reason for the greater predisposition to CAE of the right coronary artery is not clear. The left main coronary artery is less commonly involved. Some studies have documented the association between CAE and the presence of aneurysms in other vascular beds [3, 5].

Various mechanisms have been postulated in the pathogenesis of coronary dilatation. More than half of CAE cases are due to coronary atherosclerosis, whereas other possible etiologies are related to congenital abnormalities, degenerative, inflammatory, connective tissue diseases and genetic predisposition. Coronary artery ectasia is associated with classical cardiovascular risk factors except for diabetes, which is rare in patients with CAE. Its coexistence with coronary atherosclerosis suggests that ectasia may represent a variant of coronary artery atherosclerosis; however, a definite link has not yet been confirmed [3].

Coronary dilatation leads to a disturbed flow and therefore activation of the coagulation cascade. Therefore, Coronary artery ectasias are prone to thrombus formation, spasm and spontaneous dissection that predispose to exercise-induced angina, myocardial infarction and possibly sudden cardiac death. Patients with CAE without obstructive atherosclerosis may present with angina pectoris, positive stress tests or acute coronary syndromes.

The prognostic significance of CAE is unclear. Some, but not all, studies showed an increased rate of cardiovascular events in patients with CAE, but the clinical course and long-term prognosis depend mainly on whether it is isolated or co-exists with a coronary artery disease [6-8].

Coronary artery ectasia has been classified by Markis et al. on the basis of the number and diffuseness of involved coronary vessels [7]. According to the Markis classification, CAE can be categorized in four distinct types in decreasing order of severity: type I, diffuse ectasia of two or three vessels; type II, diffuse disease in one vessel and localized disease in another vessel; type III, diffuse ectasia of one vessel only; type IV, localized or segmental ectasia. According to some publications, type IV is the most common variant and type II the least frequent one [2]. This classification may have prognostic value, predicting the worst outcomes in types I and II [7, 9]. Our patient had diffuse ectasia of all four main epicardial coronary vessels.

Coronary artery ectasia can be recognized using various imaging modalities. Coronary computed tomography angiography is a feasible technique to identify and evaluate the morphology of CAE. In rare cases, all major epicardial coronary vessels can be affected by CAE. Many unanswered questions remain regarding the exact etiology and its real clinical impact. There are no studies evaluating the optimal therapy for CAE. In the absence of significant stenosis, treatment has not been well established. Anticoagulant therapy and administration of antiplatelet drugs may be attempted to prevent thromboembolic complications. Due to the lack of guidelines, management recommendations are based on personal experiences and the extent of coronary dilatation and concomitant obstructive coronary artery disease.

\section{Conclusions}

Our case indicates that CCTA is a valuable imaging modality to identify and evaluate diffuse CAE.

\section{Disclosure}

Authors report no conflict of interest.

\section{References}

1. Leschka S, Stolzmann P, Scheffel H, Wildermuth S, Plass A, Genoni M, Marincek B, Alkadhi H. Prevalence and morphology of coronary artery ectasia with dual-source CT coronary angiography. Eur Radiol 2008; 18: 27762784.

2. Zeina AR, Sharif D, Blinder J, Rosenschein U, Barmeir E. Noninvasive assessment of coronary artery ectasia using multidetector computed tomography. Coron Artery Dis 2007; 18: 175-180.

3. Farrag A, Faramawy AE, Salem MA, Wahab RA, Ghareeb S. Coronary artery ectasia diagnosed using multidetector computed tomography: morphology and relation to coronary artery calcification. Int J Cardiovasc Imaging 2013; 29: 427-433.

4. Yang J, Yang X, Chen ZY, Wang Q, He B, Du LS, Chen YD. Prevalence of coronary artery ectasia in older adults and the relationship with epicardial fat volume by cardiac computed tomography angiography. J Geriatr Cardiol 2013; 10: 10-15.

5. Pinar Bermúdez E, López Palop R, Lozano Martínez-Luengas I, Cortés Sánchez R, Carrillo Sáez P, Rodríguez Carreras R, Picó Aracil F, Valdés Chávarri M. Coronary ectasia: prevalence, and clinical and angiographic characteristics. Rev Esp Cardiol 2003; 56: 473-479.

6. Demopoulos VP, Olympios CD, Fakiolas CN, Pissimissis EG, Economides NM, Adamopoulou E, Foussas SG, Cokkinos DV. The natural history of aneurismal coronary artery disease. Heart 1997; 78: 136-141.

7. Markis JE, Joffe CD, Cohn PF, Feen DJ, Herman MV, Gorlin R. Clinical significance of coronary arterial ectasia. Am J Cardiol 1976; 37: 217-222.

8. Lin CT, Chen CW, Lin TK, Lin CL. Coronary artery ectasia. Tzu Chi Med J 2008; 20: 270-274.

9. Amirzadegan AR, Davoodi G, Soleimani A, Lotfi Tokaldany M, Hakki Kazazi E, Shabpiray H, Khorsand Askari M. Association between traditional risk factors and coronary artery ectasia: a study on 10057 angiographic procedures among Iranian population. J Tehran Heart Cent 2014; 9: 27-32.

10. Wasilewski J, Desperak P. Proximal LAD atherosclerosis: milking-like effect of the septal perforator branches. Jpn J Radiol 2015; 33: 523-524. 